\title{
Does Corporate Environmental Responsibility Engagement affect Firm Value? The Mediating Role of Corporate Innovation
}

\author{
Zhenghui Li 1 Gaoke Liao 2 Khaldoon Albitar 3 \\ 1 Guangzhou International Institute of Finance and Guangzhou University, Guangzhou, China \\ ${ }_{2}$ College of Finance and Statistics, Hunan University, Changsha, China \\ ${ }_{3}$ Faculty of Business and Law, University of Portsmouth, Portsmouth, United Kingdom \\ Zhenghui Li (lizh@gzhu.edu.cn ) \\ Gaoke Liao, Corresponding Author (liaogaoke@hnu.edu.cn , T:+8615387595621 ) \\ Khaldoon Albitar (khaldoon.albitar@port.ac.uk )
}

\begin{abstract}
This paper aims to construct a comprehensive CER engagement measurement to examine the relationship between CER engagement and firm value as well as exploring the mediating effect of corporate innovation on this relationship based on a sample of 496 China's A-share listed companies from 2008 to 2016, the results show that when firms start to adopt environmental regulations, CER would have a negative effect on firm value, however at a specific level, CER would start to enhance firm value positively. In addition to this, corporate innovation plays a mediating role in the relationship between CER and firm value. Corporate innovation promotes firm value of firms with CER more than firms without CER. Overall, the findings of this paper extremely relevant for the government, investors and firm's managers and can be utilised for policy and investment decision-making, the findings encourage firms to enhance their sense of environmental responsibility in order to enhance their competitive advantages, enhance corporate innovation capabilities, and thus enhance firm value.
\end{abstract}

Keywords: corporate environmental responsibility engagement; corporate innovation; firm value.

\section{Introduction}

As environmental sustainability becoming increasingly significant to economic development, corporate environmental responsibility (CER) has become an international trend. This trend is in the line with the goal of economic development and environmental protection. CER is an expression of the firm's ability to integrate environmental factors into its daily operations and management. According to the concept of sustainable development, firm's profit and environmental protection can be 
parallel and compatible, profit maximization is no longer the only goal pursued by the firm. Therefore, CER are likely to become a source of competitive advantage (Lloret, 2016). Recently, research increasing begin to focus on CER, but most of them stay at the theoretical level and there is a lack of empirical analysis. Research on the specific connotation of CER has shown diversity, which can mainly divided into three levels: law, ethical and strategy levels. At the legal level, firms must adjust their organizational structure or take necessary adjustments to meet the minimum environmental requirements set by law (Kim et al., 2017). The ethical level refers to the process in which firms achieve a positive impact on society and the environment through transparent and participatory stakeholder relationship management, achieving corporate environmental commitment and sustainable development goals (Kolk, 2016; Phiri et al., 2019). However, at the strategic level, firms adopt some forms of environmental plans to manage their relationship with nature and achieve the unification of environmental protection and the pursuit of profit (Liu et al., 2015; Reyes-Rodríguez et al., 2016).

Last decade has shown a considerable increase in research interest in corporate social and environmental responsibility (Qiu et al., 2016; Trumpp, C., \& Guenther, 2017; Tapver, 2019). However, no attention has been given to CSR and CER in the literature as a postulate for accountability and for the promotion of ethical and responsible business practices, and most studies have been primarily from Western countries (Islam and Deegan, 2008; Lauwo et al., 2016). CER issues are increasingly important item on Chinese government's agenda for at least two reasons. First, the continuous fast growth of the Chinese economy, mainly driven by the investment in manufacturing sector and infrastructures which has caused seriously adverse impacts on the environment (Liu and Anbumozhi, 2009). Chinese government is proactively directing the away of the country from an overemphasis on growth toward more balanced approach that also addresses social and environmental issues. Second, in the recent years Chinese public is increasingly demanding their government to pay more attention to CER issues as a result of environmental pollution problems. For instance, the public outrage at the tainted milk scandal of 2008 as well as the on-going and well-publicized air pollution across major Chinese cities have generated persisting awareness and demand for CER in China. Due to these policy initiatives and public pressures, Chinese government has stepped up its demand for businesses to behave environmentally responsible.

CER is the driving factor for firms to align environmental protection with firm value. According to stakeholder theory, CER can generate good reputation among employees, consumers and other public organizations, and this not only enhancing firm value, but also enhance firms position and competitive advantages in the market (Dixon-Fowler et al., 2017). In addition to this according to the trade-off theory, CER activities bring cost increases to the firms and cannot realize benefits in the short term (Escrig-Olmedo et al., 2017). Thus, there is ongoing debate regarding the relationship between CER and firm value.

Corporate innovation is an important way for firms to fulfill CER. CER requires firms to achieve a balance between profit and environmental protection in their 
products, production processes and production behaviors, through the improvement of technology applications to achieve green innovation of products. On the one hand, as the driving force of corporate innovation activities, fulfills CER needs to adopt innovations in production processes and products to improve resource efficiency and reduce resource consumption and environmental pollution (Pedersen et al., 2018). On the other hand, corporate innovation will bring new products and better quality products to firms which helps in gaining competitive advantage, higher market share and gaining excess returns (Martinez-Conesa et al., 2017).

Previous research focus on the effect of corporate social responsibility (CSR) on firm value and lacks the perspective from CER. Some of them consider CER as an aspect which included in CSR. Further, there is an ongoing debate on the effect of CSR on firm value. Some scholars claim that CSR activities and environment protection will result insufficient resources to be invested which will be detrimental to firm value (Barnett and Salomon, 2006; Kim et al., 2018). Others, opposite with this point and argue that superior performance in the CSR and environment protection arena can confer scarce, non-replicable and hard-to-replace resources to firm, which will promote firm value (Lins et al., 2017; Wang et al., 2016). However, as the importance of environmental issues continuously increasing, the concept of CSR is insufficient to meet the theoretical development and practical application of environmental management. As part of CSR, CER is committed to corporate sustainability, so focusing on CER may lead to more reliable conclusion.

However, following the above discussion, we can say there is a controversial theoretical debate on the impact of CER on firm value as well as a lack of empirical studies on this impact. Thus several questions could be asked, whether firms have to engage in corporate environmental responsibility? Whether the relationship between corporate environmental responsibility and firm value will be affected by corporate innovation? What role does innovation play on the impact of corporate environmental responsibility on firm value? So motivated by the previous questions, it is worthwhile to have a detailed discussion regarding to this and, therefore, this paper aims to establish a CER evaluation index system to measure CER engagement and then explore the relationship between CER and firm value as well as explore the mediating role of corporate innovation on this relationship.

The main contributions of this paper are as follow. First, this paper constructs an easy-to-use CER engagement measurement tool to measure CER engagement by considering five dimensions: legal consciousness, social evaluation, eco-friendly production, low-carbon technology, and green management and this strengthen CER understanding of firms, investors and policy makers. Second, this paper empirically explores the relationship between CER and firm value. Third, we consider corporate innovation as a mediator in the relationship between CER and firm value, and provides empirical evidence for explaining the transmission mechanism of the effect of CER on firm value which help companies to better understand the value of CER and corporate innovation.

The rest of the paper is structured as follows: section 2 introduces our research hypotheses based on analyzing the relationship between CER, corporate innovation 
and firm value. Section 3 introduces the sample and variables for empirical research, and construct the CER evaluation system. In section 4, we analyze whether CER impact firm value, and explore the mediate role of corporate innovation. Section 5 provides some additional analysis and section 6 summarizes the main conclusions and puts forward policy recommendations.

\section{Research hypotheses}

\subsection{CER and firm value}

Government regulations and accountability were believed to be the dominated forces for CER in the past (Liu et al., 2010; Weber, 2014). However, if there was no pressure, then perhaps there would be a few or no CER engagement (Islam and Deegan, 2008). Because traditional economists tend to view CER as a disadvantage, and CER activities increase corporate costs and reduce profitability. The trade-off hypothesis argues that the benefits of corporate environmental activities are lower than their costs, so environmental activities weaken corporate financial performance (Preston and O'Bannon, 1997; Elsayed and Paton, 2005). Darnall and Edwards (2006) explores some reasons which could cause greater costs when adopting an environmental management system. Belal et al. (2015) find that firms in Bangladesh reluctance to take responsibility for the environmental impact of their activities, because CER involves a huge cost. Protecting the environment by improving CER may shift the firm's core resources and therefore create a relative disadvantage compared to less CER competitors. Firms have little incentive to spend more than necessary just solely to minimum compliance (Fujii et al., 2013; Trumpp and Guenther, 2017). However, many companies are now taking the initiative to engage in CER.

A positive relationship between CER and firm value can be derived from stakeholder theory. The essential tool for improve firm value is managing the core business stakeholders relationships (Hamman et al., 2010). Tantalo and Priem (2016) believe that each essential stakeholder group exist the multiple potential sources of value creation. CER is a manifestation the concern of various stakeholders on environmental issues including government, regulators, investors, customers and employees. Clarkson et al. (2011) examines whether pursuing proactive environmental strategies leads to improved financial performance and find the positive relationship between environmental activities and financial performance is robust. Lee (2016) show that the relationships between environmental responsibility performance and firms' ROE and ROA are positive and statistically significant.

Furthermore, the resource based view (RBV) and the economics based voluntary disclosure theory (VDT) argue that firms with superior CER results in a competitive advantage. Sabherwal et al. (2019) based on the RBV, environment strategies as a capability can improves firm performance. Hummel and Schlick (2016) reveal that superior sustainability performers choose high-quality sustainability disclosure to signal their superior performance to the market which consistent with VDT. Pollution is a waste of resources, it increase the cost of the firms. The efforts to reduce pollution (CER) can not only reduces firms' environmental costs (Henri et al., 2016) but also 
reduces firms' equity financing costs (El Ghoul et al., 2018). The development of environment-related capabilities and the direct reduction of costs related to more efficient use of natural resources may particularly enhance firm value (Dixon-Fowler et al., 2017).

Based on stakeholder theory, RBV and VDT, proactively fulfilling CER can generate new competitive resources for firms therefore this will lead to a positive relationship between CER and firm value. Thus, we propose:

H1: CER is positively related to firm value.

\subsection{CER and corporate innovation}

The impact of CER on corporate innovation are from internal environmental management and the pressure of external stakeholders. Because CER is the embodiment of the integration of environmental protection into corporate strategic management, it is also the embodiment of the demand for green products by stakeholders. Proactive environmental strategies and management should integrated with corporate innovation, to make environmental sustainability efforts as a realistic activity (Wijethilake et al., 2018). Environmental strategies reflects how managers perceive the importance of CER and balance the costs and benefits of corporate innovation (Gröschl et al. 2017). Managers with a reactive environmental strategy only comply with legal regulations and view CER as burdens, whereas the proactive environmental strategy fosters firms' innovation capability (Liu et al. 2015; Song and Yu 2018). Shu et al. (2016) find that green management is more likely to lead to product innovation. Soto-Acosta et al. (2018) mentioned that environmental dynamism and management capability are positively associated with corporate innovation. Thus, CER is important driver of corporate innovation.

Corporate innovation can alleviate the increasing pressure from the stakeholders' demand for green products and service. The deterioration of the environment has prompted governments, customers, and the public to pay more attention to environmental protection and sustainable development (Marquis et al. 2015; Li et al., 2018). Facing such pressures, firms must consider how to meet the expectations of market constituents, reduce waste and protect the environment. Yang et al. (2018) reveal that managers' perceived business and social pressures are positively associated with their focus on proactive environmental strategy, which consequently fosters innovation capability development. Kawai et al. (2018) drawing upon stakeholder theory and institutional theory explain that stakeholder pressures prompt corporate innovation. Consumer perception, interest group pressure and sufficient CER to motivate firms to develop, engage and use more environmental friendly products, processes and management systems.

Effective corporate environmental responsibility requires firms to engage more in innovative activities to achieve high level of engagement in environmental responsibility so corporate innovation considers as an essential way to achieve the goal of CER. Thus, we propose:

$\mathrm{H} 2$ : CER is positively related to corporate innovation. 


\subsection{Corporate innovation and firm value}

Many previous literature claim that corporate innovation is essentially linked to higher firm value (Bos-Brouwers, 2010; Pedersen, et al., 2018). Corporate innovation is considered to be one of the key factors that influence the long-term success of the firm in today's competitive markets (Naranjo-Valencia et al., 2016; Kwakwa et al., 2018). Corporate innovation can lead to differentiation of products or services, such as lower costs, higher quality or enable firms to gain competitive advantage in the market, and ultimately enhance firm value. Firms with high level of innovative can flexibly adapt to the ever-changing market and maintain stable market competitiveness, so that firm value is continuously improved. Doran and Ryan (2016) found that corporate innovation is a powerful tool, which can be used by new firms to undermine established firms and by established firms which need to maintain their competitive position in dynamic markets. Rajapathirana and Hui (2018) argue that corporate innovation is widely regarded as pinnacle success factor in highly competitive and global economy, an innovation perspective draws clear picture of future opportunities that lie ahead.

Further, previous literature suggests that there is a lack of understanding how CER initiatives may improve firm value through corporate innovation. Aguinis and Glavas (2012) based on extensive literature reveals that there is a clear gap related to the adoption of different methods studying CSR and what could affect the relationship between CSR and firm value. Therefore, we need to understand the mechanisms linking CER with firm value. Corporate innovation is an important way for firms to fulfill CER and improve firm value. With the development of information technology and the complexity of user demand, CER requires firms to provide high-quality products and services to consumers, establish cooperation and win-win relationship with suppliers and customers, and produce more environmentally products through corporate innovation (Provasnek et al., 2017; Chuang and Huang, 2018).

Corporate innovation is not only influence firm value but also considers as a crucial factor to achieve CER so considering corporate innovation as a mediator when exploring the relationship between CER engagement and firm value will provide more accurate results and explanation to this relationship. Thus, we propose:

H3: Corporate innovation mediates the relationship between CER and firm value.

\section{Research design}

\subsection{Sample}

The initial sample of this study employs all firms listed on the A-shares (RMB ordinary stock $)^{1}$ from China Security Market from 2008 to 2016. We exclude firm-years that are missing necessary data for the variables used in our analysis. We

\footnotetext{
1 A-shares represent publicly listed Chinese companies that trade on Chinese stock exchanges such as the Shenzhen and Shanghai Stock Exchanges. These stocks trade in yuan renminbi (RMB).
} 
end up with a sample of 4464 firm-years. Data has been collected from China Stock Market \& Accounting Research (CSMAR) database, Chinese Research Data Services Platform (CNRDS) and Wind database.

\subsection{Variables and descriptive statistics}

\subsubsection{Corporate environmental responsibility}

In order to make a comprehensive evaluation, this paper evaluates CER from five dimensions: legal consciousness, social evaluation, eco-friendly production, low-carbon technology, and green management (Liu et al., 2015; Kolk, 2016; Kim et al., 2017; Reyes-Rodríguez et al., 2016; Phiri et al., 2019).

Three indicators have been used to reflect the legal consciousness dimension, the first indicator to examine whether the company follows GRI "Sustainability Reporting Guideline" as this guideline provides a direction for what companies need to do, but it is not a code of conduct and performance evaluation guideline; the second indicator to examine whether the company follows environmental law and whether it adopts relevant advocacy. The "Guidelines for Social Responsibility of Listed Companies" issued in 2006 clearly requires listed companies to regularly assess the performance of corporate social responsibility in accordance with the guidelines, but the disclosure of environmental and sustainable development engagement is not mandatory; the third indicator to examine whether the company was subjected to environmental penalties and this means whether the company has not met the minimum requirements set by law. Therefore, in the legally conscious dimension, this paper examines whether the company follows GRI Sustainability Reporting Guidelines, whether the company disclose environment and sustainable development information and whether the company was subjected to environmental penalties.

The dimension of social evaluation mainly examines whether the environmental behavior has a good reputation in society. Firms with excellent CER meet the expectations of stakeholders beyond the laws and regulations, and a good corporate reputation can enhance consumers' willingness to purchase and customer recognition. Therefore, in the dimension of social evaluation, this paper examines whether the company receives environmental commendation and whether to have environmental advantages. The dimension of eco-friendly production mainly examines whether the company causes pollution or reduces pollution during the production process. Firms which use renewable energy to adopt a circular economy model for production can reflect firm's environmental responsibility for energy use; and whether waste gas, waste water, waste residue and greenhouse gas emissions are reduced in the production process is a direct manifestation of whether the companies are conducting green production. Therefore, in the dimension of eco-friendly production, this paper examines whether the company adopts a circular economy and whether to carry out green production. The dimension of low-carbon technology mainly examines whether firms have achieved green and low-carbonization in terms of technology use. The use of low-carbon technology can transform energy use to achieve energy-saving goals; whether firms develop or use low-carbon technologies which can reflect the sustainability of corporate environmental responsibility. Therefore, in the low-carbon 
technology dimension, this paper examines whether to save energy and whether to develop or apply environmentally friendly technologies. The green management dimension mainly examines whether environmental factors are considered in the daily operations of the firms. Using third-party authentication can ensure that the firm's environmental disclosure is more objective, and can better regulate the daily behavior of the firms; Firms which have an environmentally responsible concept or vision reflects the initiative of the firms to protect the environment; Further firms which have passed ISO14001 is globally recognized and this help firms to develop their business while reducing the impact on the environment. Firms adopt green office can reflect the positive impact on the environment in corporate office activities. Therefore, in the dimension of green management, this paper examines whether to have third-party verification, whether to have an idea or vision of being responsible for the environment whether to have ISO 14001 certification and whether to adopt a green office.

Based on the above analysis, the paper establishes a CER evaluation system as shown in Table 1. In order to keep the direction of all indicators consistent, firms which have been subject to environmental penalties take the value of 0 , and firms which have not been subject to environmental penalties take the value of 1 . For the remaining indicators, if the answer is yes, firm takes the value of 1 and 0 otherwise. The indicators selected in this paper are all reflections on objective facts of the firms' behavior, and in order to avoid subjectivity of empowerment and to get more reasonable calculation of CER, this paper endows all indicators with the same weight. The score of each dimension of CER is the sum of the values of the indicators under each dimension, and CER score is the sum of scores of the five dimensions.

\subsubsection{Firm value}

Firm value generally reflects firm's ability to give all corporate stakeholders (including shareholders, creditors, managerial staff, common employees, and government) satisfying returns under value-centered management and the rule of law. Tobin's Q refers to the ratio of firm market value to its asset replacement cost, it is widely used measurement for firm value in accounting, economics, and finance literature (Brainard and Tobin, 1968; Tobin, 1969; Gompers et al., 2003). Compared to ROA, ROE and other profitability indicators, Tobin's Q considers as a better measurement of corporate performance and value. It is not only reflect past performance, but also represents the firm's future development expectations. Thus, this paper selects Tobin's $Q$ to measure firm value.

\subsubsection{Corporate innovation}

Although there are some controversies in the academic community on how to measure innovation, many scholars regard patents as the most important and most reasonable form of innovation output. China's patent system divides all patents into three categories, namely invention patents, utility model patents and design patents. The identification of invention patents is the most stringent, and the IP Office has strict requirements for the novelty, innovation and practicality of invention patents. 
Invention patents are considered to be the most high-quality, therefore, this article takes the number of corporate invention patent applications as a measure of corporate innovation (Griliches et al., 1987; Dang and Motohashi, 2015; Zhou et al., 2017).

\subsubsection{Control variables}

Several control variables have been included in the models to control factors that potentially effect firm value. We controlled for firm size, firm age, leverage, debt and liquidity, based on the extensive review of studies that used Tobin's Q as a measure for firm value (e.g., Saeidi et al., 2015; Fosu et al., 2016; Lozano et al., 2016; Kuzey and Uyar, 2017; Trumpp and Guenther, 2017). Variables description and measurements can be seen in appendix 1 .

\subsection{Model Construction}

Based on MacKinnon et al (2012) method to identify the mediating role, this paper examines the mediating role of corporate innovation between CER and firm value. A simple mediation model with one independent variable, CER, one mediator, IP, and one dependent variable, TobinQ, provides information to investigate mediation by estimating three regression equations. The relationships between CER, IP, and TobinQ are shown as path diagram in figure 1 .

Model (1) is constructed to investigate the influence of CER on firm value. The coefficient $\alpha_{1}$ represents the effect of CER on TobinQ, $\alpha_{0}$ is the intercept, and $\varepsilon_{1}$ is the residual variance.

$$
\begin{gathered}
\text { Tobin } Q=\alpha_{0}+\alpha_{1} C E R+\alpha_{2} S I Z E+\alpha_{3} A G E+\alpha_{4} D E B T+\alpha_{5} L E V E+\alpha_{6} C R \\
+ \text { TimeDummies }+ \text { IndustryFixedEffects }+\varepsilon_{1}
\end{gathered}
$$

Model (2) is constructed to observe the influence of CER on corporate innovation.

$$
\begin{gathered}
I P=\beta_{0}+\beta_{1} C E R+\beta_{2} S I Z E+\beta_{3} A G E+\beta_{4} D E B T+\beta_{5} L E V E+\beta_{6} C R \\
+ \text { TimeDummies }+ \text { IndustryFixedEffects }+\varepsilon_{2}
\end{gathered}
$$
value.

Model (3) is constructed to investigate of CER and corporate innovation on firm

$$
\begin{gathered}
\text { Tobin } Q=\theta_{0}+\theta_{1} C E R+\theta_{2} I P+\theta_{3} S I Z E+\theta_{4} A G E+\theta_{5} D E B T+\theta_{6} L E V E+\theta_{7} C R \\
+ \text { TimeDummies }+ \text { IndustryFixedEffects }+\varepsilon_{3}
\end{gathered}
$$

The most common method for testing the mediating effect is to test the regression coefficient step by step. The first step is to test the coefficient $\alpha_{1}$. If the coefficient $\alpha_{1}$ is not significant, the mediation effect analysis is stopped. If the coefficient $\alpha_{1}$ is significant, the second step is entered; the second step is to check the coefficient $\beta_{1}$ and $\theta_{2}$, if the coefficients $\beta_{1}$ and $\theta_{2}$ are significant, go to the third step; the third step checks the coefficient $\theta_{1}$. If the coefficient $\theta_{1}$ is significant, it means that there is a partial mediating effect. If the coefficient $\theta_{1}$ is not significant, it means that it is completely mediating effect; in the fourth step, if at least one of the coefficient $\beta_{1}$ and $\theta_{2}$ is not significant, the Sobel test is performed. If the Sobel 
test result is significant, the mediation effect is significant. If the Sobel test result is not significant, the mediation effect is not significant.

\section{Empirical results}

Table 2 provides the descriptive statistics of the included variables for the whole sample and for firms with CER and without CER separately. The CER level for the whole sample from 0 to 13 points with a mean score of 2.642 which reflect that many firms don't provide CER information according to our measurement and indicate that Chines companies don't consider CER dimensions in their annual reports. In addition to this, the results clearly show that no company fully obtained an overall score of 13 points according to the developed CER measurement. The correlation matrix for the dependent and independent variables are presented in Table 3. The correlation matrix shows correlation between CER index and its explanatory variables, as well as the correlations among other variables. This will help checking the statistical relationship between the dependent and the independent variables, and whether there is any potential sign of Collinearity. It can be decided that Multicollinearity does not appear to be a concern in explaining the results from VIF results which tested separately.

Table 4 shows the regression results for the constructed models, Model (1) used to test the first hypothesis which states that CER is positively related to firm value. Here DCER is considered as dummy variable so we gave 1 for firms with any level of CER and 0 for firms without CER. The findings of the study discover that firms with CER are conducive to enhance firm value measured by Tobin'Q which similar to previous research (Lee 2016; Dixon-Fowler et al., 2017; Sabherwal et al. 2019). Moreover, the results from Model 2 further divulge that the coefficient of corporate innovation measured by invention patents is positive and significant which confirms that firms which involve in CER are conducive to simulate corporate innovation. The results when running Model 3 show that corporate innovation enhance firm value. In addition to this, CER promotes corporate innovation and thus enhance firm value which confirm that corporate innovation plays a mediating role in the relationship between CER and firm value.

Following this, we divided our sample into two sub-samples, firms with a specific level of CER and firms without any CER level according to our measurement. Then, we excluded firms without CER and run the analysis. Here, we used the real CER points for each firm which rang between (1 to13) and as it can be seen in table 5 . Surprisingly, the results from running the first model show a significant negative relationship between CER and firm value with coefficient of -0.0411 which reflect that firms with high CER will inhibitory effect firm value. However, the results from the second model show a significant positive relationship between CER and firm innovation showing that firms which improve CER conducive to simulate corporate innovation confirming our first results when running the whole sample. Interestingly, the results from this table also show that the total effect of CER on firm value is -0.0411 and the direct effect of CER on firm value is -0.0429 , which indicates that CER has a negative impact on firm value and the total impact is greater than the direct impact by $0.0018\{-0.0411-(-0.0429)\}$. The indirect effect of CER on firm value is $0.0018(0.0396 * 0.0470)$, which indicates that CER will reduce the negative impact of 
CER on FV through corporate innovation. Corporate innovation partly mediates the relationship between CER and firm value and corporate innovation as a mediator reduces the adverse effects of CER on firm value.

\section{Additional analysis}

As it can be seen from table 6, we divided the CER sample into 3 sub-samples, 1 . Firms with low level of CER (we call it CER 1), include firms which got from (1 to 4 points) according to the CER measurement. 2. Firms with medium level of CER (we call it CER 2), which include firms with (5 or 6 points). 3. Firms with high level of CER (we call it CER 3) which include firms with 7 points or more. The coefficients of CER1, CER2 and CER3 are positive, indicating firms with low, medium and high level of CER have higher value than those without CER firms. The coefficient of CER1 is 0.2507, which is larger than the coefficients of CER2 and CER3 which means that firms with low-level CER have the highest firm value. This further illustrates that CER have a negative impact on firm value when considering CER sample. However, the coefficient of CER2 is 0.1796, which is smaller than the coefficient of CER3. This shows that firms with high level of CER have higher value than those with medium CER companies. This confirms that CER will not always have a negative impact on firm value, and the impact of CER on firm value is non-linear. Although the coefficient of CER3 is still lower than CER1, this is because China's corporate environmental responsibility is still in its early stages. In addition to this, stakeholders and firms pay less attention to corporate environmental responsibility so the firm can't get enough profit from CER activities. However, the results show that innovation will always increase firm value, the impact of innovation on firm value is different when we compare between CER and no CER firms. The coefficient of CER $0 *$ INP is 0.0629 , which is much smaller than the coefficients of CER $1 *$ INP, CER $2 *$ INP and CER $3 *$ INP, indicating that innovation can increase firm value when firm involves in environmental responsibility. Nevertheless, when we compare different CER levels, there is no significant differences in the impact of innovation on firm value.

\section{Conclusion}

As environmental protection and energy saving organisations around the world have required firms to be involved and to disclose more information related to CER, firms may consider this as a source of competitive advantage. Further, as environmental issues become crucial, people's environmental awareness becomes higher, and corporate environmental responsibility will bring greater benefits to firms. From a theoretical perspective, the relationship between CER and firm value is very obvious, especially when considering the influence of corporate innovation on this relationship. Moreover, although some previous research explore the direct impact of CER on firm value, to the best of our knowledge, no previous study considers the mediating role of Corporate innovation on the relationship between CER and firm value. In one hand, this research investigates the relationship between CER and firm value by developing a comprehensive CER engagement measurement. In the other 
hand, it tests the mediating role of corporate innovation measured by invention patents on the relationship between CER and firm value applying data from a sample of 496 China's A-share listed companies from 2008 to 2016. The results showed that corporate innovation plays a positive mediating role in the relationship between CER and firm value. Innovation therefore represents an indispensable tool to the implementation of CER. Thus, firms should take environmental protection into consideration while pursuing economic development. China government should support firms to be involved in CER by giving them subsidies to lower their environmental cost at the early stages, firms have to be involved in CER, through innovation as well. The Chinese government should further improve environmental regulations, strengthen government supervision, encouraging firms to undertake more CER engagement. Thus, this paper contributes to the literature by constructing an easy-to-use measurement for CER engagement, as well as considering the role of corporate innovation when exploring the relationship between CER and firm value, which provides new empirical evidence to explain the effect of CER engagement on firm value which help companies to better understand the value of CER and corporate innovation.

Overall, the findings of this paper extremely relevant for the government, investors and firm's managers and can be utilised for policy and investment decision-making. For instance, firms may improve CER engagement in order to enhance their competitive advantages and increase firm value by enhancing corporate innovation as well. Policymakers may encourage firms to engage and disclose more CER information by increasing both transparency and coherence of CER policies or issue new compulsory regulations for CER and Innovation. This study investigates the effect of CER engagement on firm value, however, since China is an emerging country, CER data for medium and long-term listed firms is not available yet, therefore, future research could explore whether there is any difference of CER engagement on firm value in the long and short-term. Further, due to the lack of financial data, firms number in some industries is too low so the heterogeneity between industries has not been considered in this paper when exploring the effect of CER on firm value so future research could also explore whether there are significant differences between different industries as different industries could have different needs of CER engagement and corporate innovation.

\section{References}

Aguinis, H., \& Glavas, A. (2012). What we know and don't know about corporate social responsibility: A review and research agenda. Journal of management, 38(4), 932-968. https://doi:10.1177/0149206311436079

Barnett, M. L., \& Salomon, R. M. (2006). Beyond dichotomy: The curvilinear relationship between social responsibility and financial performance. Strategic management journal, 27(11), 1101-1122. https://doi:10.1002/smj.557 
Belal, A., Cooper, S.M., \& Khan, N. A. (2015). Corporate environmental responsibility and accountability: What chance in vulnerable Bangladesh?. Critical Perspectives on Accounting, 33, 44-58. https://doi:10.1016/j.cpa.2015.01.005

Bos-Brouwers, H. E. J. (2010). Corporate sustainability and innovation in SMEs: evidence of themes and activities in practice. Business strategy and the environment, 19(7), 417-435. https://doi:10.1002/bse.652

Brainard, W., \& Tobin, J. (1968). Pitfalls in financial model building. American Economic Review, 58, 99-122.

Chuang, S. P., \& Huang, S. J. (2018). The effect of environmental corporate social responsibility on environmental performance and business competitiveness: The mediation of green information technology capital. Journal of Business $\quad$ Ethics, 150(4), https://doi:10.1007/s10551-016-3167-X

Clarkson, P. M., Li, Y., Richardson, G. D., \& Vasvari, F. P. (2011). Does it really pay to be green? Determinants and consequences of proactive environmental strategies. Journal of Accounting and Public Policy, 30(2), 122-144. https://doi:10.1016/j.jaccpubpol.2010.09.013

Coad, A., Segarra, A., \& Teruel, M. (2016). Innovation and firm growth: Does firm age play a role? Research Policy, 45(2), 387-400. https://doi:10.1016/j.respol.2015.10.015

Dang, J., \& Motohashi, K. (2015). Patent statistics: A good indicator for innovation in China? Patent subsidy program impacts on patent quality. China Economic Review, 35, 137-155. https://doi:10.1016/j.chieco.2015.03.012

Darnall, N., \& Edwards Jr, D. (2006). Predicting the cost of environmental management system adoption: the role of capabilities, resources and ownership structure. Strategic management journal, 27(4), 301-320. https://doi:10.1002/smj.518

Dixon-Fowler, H. R., Ellstrand, A. E., \& Johnson, J. L. (2017). The role of board environmental committees in corporate environmental performance. Journal of Business Ethics, 140(3), 423-438. https://doi:10.1007/s10551-015-2664-7

Doran, J., \& Ryan, G. (2016). The importance of the diverse drivers and types of environmental innovation for firm performance. Business strategy and the environment, 25(2), 102-119. https://doi:0.1002/bse.1860

El Ghoul, S., Guedhami, O., Kim, H., \& Park, K. (2018). Corporate environmental responsibility and the cost of capital: International evidence. Journal of Business Ethics, 149(2), 335-361. https://doi:10.1007/s10551-015-3005-6

Elsayed, K., \& Paton, D. (2005). The impact of environmental performance on firm performance: static and dynamic panel data evidence. Structural change and economic dynamics, 16(3), 395-412. https://doi:10.1016/j.strueco.2004.04.004

Escrig-Olmedo, E., Muñoz-Torres, M. J., Fernández-Izquierdo, M. Á., \& Rivera-Lirio, J. M. (2017). Measuring corporate environmental performance: a methodology for sustainable development. Business Strategy and the Environment, 26(2), 142-162. https://doi:10.1002/bse.1904

Fosu, S., Danso, A., Ahmad, W., \& Coffie, W. (2016). Information asymmetry, leverage and firm value: Do crisis and growth matter?. International Review of Financial Analysis, 46, 140-150. https://doi:10.1016/j.irfa.2016.05.002

Fujii, H., Iwata, K., Kaneko, S., \& Managi, S. (2013). Corporate environmental and economic performance of Japanese manufacturing firms: Empirical study for sustainable development. Business Strategy and the Environment, 22(3), 187-201. https://doi:10.1002/bse.1747 
Gompers, P. A., Ishii, J. L., \& Metrick, A. (2003). Corporate governance and equity prices. Quarterly Journal of Economics, 118(1), 107-155. https://doi:10.1162/00335530360535162

Griliches, Z., Pakes, A., \& Hall, B. (1987). The value of patents as indicators of inventive activity. In P. Dasgupta \& P. Stoneman (Eds.), Economic policy and technological performance. Cambridge, MA: Cambridge University Press.

Gröschl, S., Gabaldón, P., \& Hahn, T. (2017). The co-evolution of leaders' cognitive complexity and corporate sustainability: The case of the CEO of Puma. Journal of Business Ethics. https ://doi.org/10.1007/s1055 1-017-3508-4

Hamman, J. R., Loewenstein, G., \& Weber, R. A. (2010). Self-interest through delegation: An additional rationale for the principal-agent relationship. American Economic Review, 100(4), 1826-46. https://doi:10.1257/aer.100.4.1826

Henri, J. F., Boiral, O., \& Roy, M. J. (2016). Strategic cost management and performance: The case of environmental costs. The British Accounting Review, 48(2), 269-282. https://doi:10.1016/j.bar.2015.01.001

Hummel, K., \& Schlick, C. (2016). The relationship between sustainability performance and sustainability disclosure-Reconciling voluntary disclosure theory and legitimacy theory. Journal of Accounting and Public Policy, 35(5), 455-476. https://doi:10.1016/j.jaccpubpol.2016.06.001

Islam, M. A., \& Deegan, C. (2008). Motivations for an organization within a developing country to report social responsibility information: Evidence from Bangladesh. Accounting, Auditing \& Accountability Journal, 21(6), 850-874. https://doi:10.1108/09513570810893272

Kawai, N., Strange, R., \& Zucchella, A. (2018). Stakeholder pressures, EMS implementation, and green innovation in MNC overseas subsidiaries. International Business Review, 27(5), 933-946. https://doi:10.1016/j.ibusrev.2018.02.004

Kim, H., Park, K., \& Ryu, D. (2017). Corporate environmental responsibility: A legal origins perspective. Journal of Business Ethics, 140(3), 381- 402. https://doi:10.1007/s10551-015-2641-1

Kim, K. H., Kim, M., \& Qian, C. (2018). Effects of corporate social responsibility on corporate financial performance: A competitive-action perspective. Journal of Management, 44(3), 1097-1118. https://doi:10.1177/0149206315602530

Kolk, A. (2016). The social responsibility of international business: From ethics and the environment to CSR and sustainable development. Journal of World Business, 51(1), 23-34. https://doi:10.1016/j.jwb.2015.08.010

Kuzey, C., \& Uyar, A. (2017). Determinants of sustainability reporting and its impact on firm value: Evidence from the emerging market of Turkey. Journal of cleaner production, 143, 27-39. https://doi:10.1016/j.jclepro.2016.12.153

Kwakwa, P. A., Alhassan, H., \& Aboagye, S. (2018). Environmental Kuznets curve hypothesis in a financial development and natural resource extraction context: evidence from Tunisia. Quantitative Finance and Economics, 2(4), 981-1000. https://doi:10.3934/qfe.2018.4.981

Lauwo, S. G., Otusanya, O. J., \& Bakre, O. (2016). Corporate social responsibility reporting in the mining sector of Tanzania". Accounting, Auditing \& Accountability Journal, 29(6), 1038- 1074. https://doi:10.1108/aaaj-06-2013-1380

Lee, K. H., Cin, B. C., \& Lee, E. Y. (2016). Environmental responsibility and firm performance: the application of an environmental, social and governance model. Business Strategy and the Environment, 25(1), 40-53. https://doi:10.1002/bse.1855 
Li, Z., Liao, G., Wang, Z., \& Huang, Z. (2018). Green loan and subsidy for promoting clean production innovation. Journal of Cleaner Production, 187, 421-431. https://doi:10.1016/j.jclepro.2018.03.066

Lins, K. V., Servaes, H., \& Tamayo, A. (2017). Social capital, trust, and firm performance: The value of corporate social responsibility during the financial crisis. The Journal of Finance, 72(4), 1785-1824. https://doi:10.1111/jofi.12505

Liu X., \& Anbumozhi V. (2009). Determinant factors of corporate environmental information disclosure: an empirical study of Chinese listed companies. Journal of Cleaner Production, 17(6), 593-600. https://doi:10.1016/j.jclepro.2008.10.001

Liu, C. C., Wang, L. F., \& Lee, S. H. (2015). Strategic environmental corporate social responsibility in a differentiated duopoly market. Economics Letters, 129, 108-111. https://doi:10.1016/j.econlet.2015.02.027

Liu, X, Liu, B, Shishime, T, Yu, Q, Bi, J, \& Fujitsuka, T. (2010). An empirical study on the driving mechanism of proactive corporate environmental management in China. Journal of Environmental Management, 91(8), 1707-1717. https://doi:10.1016/j.jenvman.2010.03.011

Lloret, A., (2016). Modeling corporate sustainability strategy. Journal of Business Research, 69(2), 418-425. https://doi:10.1016/j.jbusres.2015.06.047

Lozano, M. B., Martínez, B., \& Pindado, J. (2016). Corporate governance, ownership and firm value: Drivers of ownership as a good corporate governance mechanism. International Business Review, 25(6), 1333-1343. https://doi:10.1016/j.ibusrev.2016.04.005

MacKinnon, D. P., Coxe, S., \& Baraldi, A. N. (2012). Guidelines for the investigation of mediating variables in business research. Journal of Business and Psychology, 27(1), 1-14. https://doi:10.1007/s10869-011-9248-Z

Marquis, C., Jackson, S. E., \& Li, Y. (2015). Building sustainable organizations in China. Management and Organization Review, 11(3), 427-440. https://doi:10.1017/mor.2015.37

Martinez-Conesa, I., Soto-Acosta, P., \& Palacios-Manzano, M. (2017). Corporate social responsibility and its effect on innovation and firm performance: An empirical research in SMEs. Journal of cleaner production, 142, 2374-2383. https://doi:10.1016/j.jclepro.2016.11.038

Naranjo-Valencia, J. C., Jiménez-Jiménez, D., \& Sanz-Valle, R. (2016). Studying the links between organizational culture, innovation, and performance in Spanish companies. Revista Latinoamericana de Psicología, 48(1), 30-41. https://doi:10.1016/j.rlp.2015.09.009

Pedersen, E. R. G., Gwozdz, W., \& Hvass, K. K. (2018). Exploring the relationship between business model innovation, corporate sustainability, and organisational values within the fashion industry. Journal of Business Ethics, 149(2), 267-284. https://doi:10.1007/s10551-016-3044-7

Phiri, O., Mantzari, E., \& Gleadle, P. (2019). Stakeholder interactions and corporate social responsibility (CSR) practices: Evidence from the Zambian copper mining sector. Accounting, Auditing \& Accountability Journal, 32(1), 26-54. https://doi:10.1108/aaaj-04-2016-2540

Preston, L. E., \& O'bannon, D. P. (1997). The corporate social-financial performance relationship: A typology and analysis. Business \& Society, 36(4), 419-429. https://doi:10.1177/000765039703600406 Provasnek, A. K., Schmid, E., Geissler, B., \& Steiner, G. (2017). Sustainable corporate entrepreneurship: Performance and strategies toward innovation. Business Strategy and the Environment, 26(4), 521-535. https://doi:10.1002/bse.1934

Qiu, Y., Shaukat, A., \& Tharyan, R. (2016). Environmental and social disclosures: Link with corporate financial performance. The British Accounting Review, 48(1), 102-116. https://doi:10.1016/j.bar.2014.10.007 
Rajapathirana, R. J., \& Hui, Y. (2018). Relationship between innovation capability, innovation type, and firm performance. Journal of Innovation \& Knowledge, 3(1), 44-55. https://doi:10.1016/j.jik.2017.06.002

Reyes-Rodríguez, J. F., Ulhøi, J. P., \& Madsen, H. (2016). Corporate environmental sustainability in Danish SMEs: A longitudinal study of motivators, initiatives, and strategic effects. Corporate Social Responsibility and Environmental Management, 23(4), 193-212. https://doi:10.1002/csr.1359

Sabherwal, R., Sabherwal, S., Havakhor, T., \& Steelman, Z. (2019). How does strategic alignment affect firm performance? The roles of information technology investment and environmental uncertainty. MIS Quart, 42(2), 453-474. https://doi:10.25300/misq/2019/13626

Saeidi, S. P., Sofian, S., Saeidi, P., Saeidi, S. P., \& Saaeidi, S. A. (2015). How does corporate social responsibility contribute to firm financial performance? The mediating role of competitive advantage, reputation, and customer satisfaction. Journal of business research, 68(2), 341-350. https://doi:10.1016/j.jbusres.2014.06.024

Shu, C., Zhou, K. Z., Xiao, Y., \& Gao, S. (2016). How green management influences product innovation in China: The role of institutional benefits. Journal of Business Ethics, 133(3), 471-485. https://doi:10.1007/s10551-014-2401-7

Song, W., \& Yu, H. (2018). Green innovation strategy and green innovation: The roles of green creativity and green organizational identity. Corporate Social Responsibility and Environmental Management, 25(2), 135-150. https://doi:10.1002/csr.1445

Soto-Acosta, P., Popa, S., \& Martinez-Conesa, I. (2018). Information technology, knowledge management and environmental dynamism as drivers of innovation ambidexterity: a study in SMEs. Journal of Knowledge Management, 22(4), 824-849. https://doi:10.1108/jkm-10-2017-0448

Tantalo, C., \& Priem, R. L. (2016). Value creation through stakeholder synergy. Strategic Management Journal, 37(2), 314-329. doi.org/10.1002/smj.2337

Tapver, T. (2019). CSR reporting in banks: does the composition of the board of directors matter? Quantitative Finance and Economics, 3(2): 286-314. https://doi:10.3934/qfe.2019.2.286

Tobin, J. (1969). A general equilibrium approach to monetary theory. Journal of Money Credit and Banking, 1(1), 15-29. https://doi:10.2307/1991374

Trumpp, C., \& Guenther, T. (2017). Too little or too much? Exploring U-shaped relationships between corporate environmental performance and corporate financial performance. Business Strategy and the Environment, 26(1), 49-68. https://doi:10.1002/bse.1900

Wang, Q., Dou, J., \& Jia, S. (2016). A meta-analytic review of corporate social responsibility and corporate financial performance: The moderating effect of contextual factors. Business \& Society, 55(8), 1083-1121. https://doi:10.1177/0007650315584317

Weber, O. (2014). Environmental, Social and Governance Reporting in China. Business Strategy and the Environment, 23(5), 303-317. https://doi:10.1002/bse.1785

Wijethilake, C., Munir, R., \& Appuhami, R. (2018). Environmental innovation strategy and organizational performance: Enabling and controlling uses of management control systems. Journal of Business Ethics, 151(4), 1139-1160. https://doi:10.1007/s10551-016-3259-7

Yang, D., Wang, A. X., Zhou, K. Z., \& Jiang, W. (2018). Environmental strategy, institutional force, and innovation capability: A managerial cognition perspective. Journal of Business Ethics, 1-15. https://doi:10.1007/s10551-018-3830-5 
Zhou, K. Z., Gao, G. Y., \& Zhao, H. (2017). State ownership and firm innovation in China: An integrated view of institutional and efficiency logics. Administrative Science Quarterly, 62(2), 375-404. https://doi:10.1177/0001839216674457

Table 1

Measuring corporate environmental responsibility engagement

Dimensions Indicator name

\begin{tabular}{|c|c|}
\hline $\begin{array}{l}\text { Legal } \\
\text { consciousness }\end{array}$ & $\begin{array}{l}\text { 1. Whether to follow the GRI Sustainability Reporting Guidelines; } 2 . \\
\text { Whether to disclose the environment and sustainable development } \\
\text { information; } 3 \text {. Whether subjected to environmental penalties. }\end{array}$ \\
\hline Social evaluation & $\begin{array}{l}\text { 1. Whether to receive environmental commendation; } 2 \text {. Whether to have } \\
\text { environmental advantages. }\end{array}$ \\
\hline $\begin{array}{l}\text { Eco-friendly } \\
\text { production }\end{array}$ & $\begin{array}{l}\text { 1. Whether to adopt a circular economy; } 2 \text {. Whether to carry out green } \\
\text { production. }\end{array}$ \\
\hline $\begin{array}{l}\text { Low-carbon } \\
\text { technology }\end{array}$ & $\begin{array}{l}\text { 1. Whether to save energy; } 2 \text {. Whether to develop or apply } \\
\text { environmentally friendly technologies. }\end{array}$ \\
\hline $\begin{array}{c}\text { Green } \\
\text { management }\end{array}$ & $\begin{array}{l}\text { 1. Whether to have third-party verification; } 2 \text {. Whether to have an idea or } \\
\text { vision of being responsible for the environment; } 3 \text {. Whether to have ISO } \\
14001 \text { certification; } 4 \text {. Whether to adopt a green office. }\end{array}$ \\
\hline
\end{tabular}

\section{Table 2}

Descriptive statistics

\begin{tabular}{ccccccc}
\hline & Variable & Obs & Mean & Std. Dev. & Min & Max \\
\hline \multirow{4}{*}{ Whole } & TobinQ & 4,464 & 2.339448 & 1.586357 & 0.219053 & 20.1447 \\
& CER & 4,464 & 2.642697 & 3.244848 & 0 & 12 \\
& IP & 4,464 & 2.652142 & 1.504699 & 0 & 8.787525 \\
& SIZE & 4,464 & 22.43802 & 1.423713 & 19.04556 & 28.50873 \\
& AGE & 4,464 & 11.54032 & 5.457898 & 0 & 26 \\
& LEVE & 4,464 & 2.323567 & 19.14329 & -590.128 & 374.7753 \\
& DEBT & 4,464 & 0.4878628 & 0.1935426 & 0.0187715 & 1.303486 \\
& CR & 4,464 & 1.7807 & 1.681821 & 0.1025854 & 26.29951 \\
\hline
\end{tabular}




\begin{tabular}{ccccccc}
\hline & TobinQ & 1,853 & 2.103133 & 1.385861 & 0.704995 & 15.11344 \\
& CER & 1,853 & 5.195899 & 1.904282 & 1 & 11 \\
& IP & 1,853 & 3.217022 & 1.640592 & 0 & 8.787525 \\
Decr=1 & SIZE & 1,853 & 23.25594 & 1.517095 & 19.54107 & 28.50873 \\
& AGE & 1,853 & 12.16514 & 5.245561 & 0 & 26 \\
& LEVE & 1,853 & 2.783472 & 16.28691 & -514.8911 & 374.7753 \\
& DEBT & 1,853 & 0.5082987 & 0.1823934 & 0.0370451 & 0.9717411 \\
& CR & 1,853 & 1.662901 & 1.644849 & 0.153912 & 24.0852 \\
& TobinQ & 2,611 & 2.507158 & 1.694862 & 0.219053 & 20.1447 \\
& CER & 2,611 & 0 & 0 & 0 & 0 \\
& IP & 2,611 & 2.251253 & 1.254743 & 0 & 6.504288 \\
& SIZE & 2,611 & 21.85754 & 1.01036 & 19.04556 & 26.25307 \\
& AGE & 2,611 & 11.0969 & 5.562273 & 0 & 26 \\
& LEVE & 2,611 & 1.997177 & 20.93227 & -590.128 & 237.8904 \\
& DEBT & 2,611 & 0.4733597 & 0.1998507 & 0.0187715 & 1.303486 \\
& CR & 2,611 & 1.864301 & 1.702949 & 0.1025854 & 26.29951 \\
\hline
\end{tabular}

Table 3

Correlation matrix.

\begin{tabular}{crrrrrrrr}
\hline & \multicolumn{1}{c}{ TobinQ } & CER & IP & SIZE & AGE & LEVE & DEBT & CR \\
\hline TobinQ & 1 & & & & & & & \\
CER & $-0.1729^{* * *}$ & 1 & & & & & & \\
IP & $-0.11^{* * *}$ & $0.3666^{* * *}$ & 1 & & & & & \\
SIZE & $-0.4225^{* * *}$ & $0.557^{* * *}$ & $0.5064^{* * *}$ & 1 & & & & \\
AGE & $-0.1067^{* * *}$ & $0.1199^{* * *}$ & $0.1194^{* * *}$ & $0.2457^{* * *}$ & 1 & & & \\
LEVE & $-0.0279^{*}$ & 0.0226 & 0.012 & $0.033^{* *}$ & -0.0114 & 1 & & \\
DEBT & $-0.4068^{* * *}$ & $0.118^{* * *}$ & $0.116^{* * *}$ & $0.4315^{* * *}$ & $0.1401^{* * *}$ & $0.0315^{* *}$ & 1 & \\
CR & $0.3677^{* * *}-0.0822^{* * *}-0.0556^{* * *}-0.2514^{* * *}-0.1231^{* * *}$ & $-0.0152-0.5969^{* * *}$ & \\
\hline
\end{tabular}

Note: $* * *$, and $* * *$ statistical significance at the $10 \%, 5 \%$, and $1 \%$

\section{Table 4}

Whole sample regression results

\begin{tabular}{cccc}
\hline $\begin{array}{c}\text { Dependent } \\
\text { variable }\end{array}$ & MODEL(1) & MODEL(2) & MODEL(3) \\
Tobin'q & INP & Tobin'q \\
\hline \multirow{2}{*}{ DCER } & $0.2169^{* * * *}$ & $0.2375^{* * *}$ & $0.1958^{* * *}$ \\
& $(0.000)$ & $(0.000)$ & $(0.000)$ \\
IP & & & $0.0889^{* * *}$ \\
& & & $(0.000)$ \\
SIZE & $-0.4336^{* * *}$ & $0.6392^{* * *}$ & $-0.4905^{* * *}$ \\
& $(0.000)$ & $(0.000)$ & $(0.000)$ \\
AGE & $-0.01569^{* * *}$ & $-0.0301^{* * *}$ & $-0.01302^{* * *}$ \\
& $(0.000)$ & $(0.000)$ & $(0.002)$ \\
\hline
\end{tabular}




\begin{tabular}{cccc}
\hline LEVE & -0.0007 & -0.0008 & -.0007 \\
& $(0.454)$ & $(0.394)$ & $(0.497)$ \\
DEBT & $-0.8732^{* * *}$ & $-0.6975^{* * *}$ & $-0.8111^{* * *}$ \\
& $(0.000)$ & $(0.000)$ & $(0.000)$ \\
CR & $0.1891^{* * *}$ & $0.0003^{* * *}$ & $0.1890^{* * *}$ \\
& $(0.000)$ & $(0.000)$ & $(0.000)$ \\
Intercept & $11.3355^{* * *}$ & $-11.6514 * * *$ & $12.3718^{* * *}$ \\
& $(0.000)$ & $(0.000)$ & $(0.000)$ \\
Year effect & YES & YES & YES \\
Industry effect & YES & YES & YES \\
$\mathrm{N}$ & 4464 & 4464 & 4464 \\
Adj $\mathrm{R}^{2}$ & 0.3899 & 0.3888 & 0.3977 \\
\hline
\end{tabular}

Note: P-value is in parentheses. *,**, and $* * *$ statistical significance at the $10 \%, 5 \%$, and $1 \%$

Table 5

CER sample regression results

\begin{tabular}{|c|c|c|c|}
\hline $\begin{array}{c}\text { Dependent } \\
\text { variable }\end{array}$ & $\begin{array}{c}\text { MODEL(1) } \\
\text { Tobin'q }\end{array}$ & $\begin{array}{c}\text { MODEL(2) } \\
\text { INP } \\
\end{array}$ & $\begin{array}{c}\text { MODEL(3) } \\
\text { Tobin'q }\end{array}$ \\
\hline CER & $\begin{array}{c}-0.0411 * * * \\
(0.006)\end{array}$ & $\begin{array}{c}0.0396 * * \\
(0.024)\end{array}$ & $\begin{array}{c}-0.0429 * * * \\
(0.004)\end{array}$ \\
\hline INP & & & $\begin{array}{c}0.0470^{* *} \\
(0.019)\end{array}$ \\
\hline SIZE & $\begin{array}{c}-0.2724 * * * \\
(0.000)\end{array}$ & $\begin{array}{c}0.7097^{* * *} * \\
(0.000)\end{array}$ & $\begin{array}{c}-0.3057^{* * *} * \\
(0.000)\end{array}$ \\
\hline AGE & $\begin{array}{c}-0.0207 * * * \\
(0.000)\end{array}$ & $\begin{array}{c}-0.0339 \text { *** } \\
(0.000)\end{array}$ & $\begin{array}{c}-0.0192 * * * \\
(0.001)\end{array}$ \\
\hline LEVE & $\begin{array}{l}-0.0013 \\
(0.398)\end{array}$ & $\begin{array}{c}-0.0051^{* *} \\
(0.005)\end{array}$ & $\begin{array}{l}-.0011 \\
(0.490)\end{array}$ \\
\hline DEBT & $\begin{array}{c}-1.7400^{* * * *} \\
(0.000)\end{array}$ & $\begin{array}{c}-0.6196 * * * \\
(0.006)\end{array}$ & $\begin{array}{c}-1.7109 * * * * \\
(0.000)\end{array}$ \\
\hline $\mathrm{CR}$ & $\begin{array}{c}0.1131^{* * * *} \\
(0.000)\end{array}$ & $\begin{array}{l}0.0056 \\
(0.798)\end{array}$ & $\begin{array}{c}0.1128^{* * *} * \\
(0.000)\end{array}$ \\
\hline Intercept & $\begin{array}{c}8.341 \text { **** } \\
(0.000)\end{array}$ & $\begin{array}{c}-13.3752^{* * *} * \\
(0.000)\end{array}$ & $\begin{array}{c}9.50588 \text { *** } \\
(0.000)\end{array}$ \\
\hline Year effect & YES & YES & YES \\
\hline Industry effect & YES & YES & YES \\
\hline $\mathrm{N}$ & 1853 & 1853 & 1853 \\
\hline $\operatorname{Adj} R^{2}$ & 0.4032 & 0.4218 & 0.4047 \\
\hline
\end{tabular}

Note: P-value is in parentheses. *, **, and *** statistical significance at the $10 \%, 5 \%$, and $1 \%$

\section{Table 6}

Additional analysis 


\begin{tabular}{|c|c|c|c|}
\hline $\begin{array}{l}\text { Dependent } \\
\text { variable }\end{array}$ & Tobin'q & & \\
\hline CER0*INP & $\begin{array}{c}0.0629 * * * \\
(0.000)\end{array}$ & & \\
\hline CER $1 *$ INP & $\begin{array}{c}0.1246^{* * * *} \\
(0.000)\end{array}$ & CER1 & $\begin{array}{c}0.2507^{* * *} * \\
(0.000)\end{array}$ \\
\hline CER2*INP & $\begin{array}{c}0.1126 * * * \\
(0.000)\end{array}$ & CER2 & $\begin{array}{c}0.1796 * * * \\
(0.002)\end{array}$ \\
\hline CER3*INP & $\begin{array}{c}0.1141^{* * *} * \\
(0.000)\end{array}$ & CER3 & $\begin{array}{c}0.2164 \text { *** } \\
(0.005)\end{array}$ \\
\hline SIZE & $\begin{array}{c}-0.4853^{* * *} * \\
(0.000)\end{array}$ & & $\begin{array}{c}-0.4320^{* * * *} \\
(0.000)\end{array}$ \\
\hline AGE & $\begin{array}{c}-.0129 * * * \\
(0.000)\end{array}$ & & $\begin{array}{c}-0.0158 * * * * \\
(0.001)\end{array}$ \\
\hline LEVE & $\begin{array}{c}-0.0006^{* * * *} \\
(0.000)\end{array}$ & & $\begin{array}{l}-0.0007 \\
(0.445)\end{array}$ \\
\hline DEBT & $\begin{array}{c}-0.8311 * * * \\
(0.000)\end{array}$ & & $\begin{array}{c}-0.8725^{* * * *} \\
(0.000)\end{array}$ \\
\hline $\mathrm{CR}$ & $\begin{array}{c}0.1889 * * * \\
(0.000)\end{array}$ & & $\begin{array}{c}0.1893^{* * *} * \\
(0.000)\end{array}$ \\
\hline Intercept & $\begin{array}{c}12.3354^{* * * *} \\
(0.000)\end{array}$ & & $\begin{array}{c}11.2982^{* * *} \\
(0.000)\end{array}$ \\
\hline Year effect & YES & & YES \\
\hline Industry effect & YES & & YES \\
\hline $\mathrm{N}$ & 4464 & & 4464 \\
\hline Adj $R^{2}$ & 0.3932 & & 0.3898 \\
\hline
\end{tabular}

Note: P-value is in parentheses. *,**, and *** statistical significance at the $10 \%, 5 \%$, and $1 \%$

\section{Appendix 1}

Variable description

\begin{tabular}{|l|l|l|}
\hline Variables & Description & Reference \\
\hline TobinQ & $\begin{array}{l}\text { Tobin's Q is calculated as: \{[Market value of common } \\
\text { stock + Book value of preferred stock + Book value of } \\
\text { long-term debt + Book value of current liabilities - (Book } \\
\text { value of current assets - Book value of inventories)]/Book } \\
\text { value of total assets }\}\end{array}$ & $\begin{array}{l}\text { Brainard and Tobin, 1968; } \\
\text { Tobin, 1969; Gompers et } \\
\text { al., 2003 }\end{array}$ \\
\hline CER & Measured by self-constructed CER evaluation system & $\begin{array}{l}\text { Griliches et al., 1987; Dang } \\
\text { and Motohashi, 2015; Zhou } \\
\text { et al., 2017 }\end{array}$ \\
\hline IP & $\begin{array}{l}\text { The number of corporate invention patent applications } \\
\text { Trumpp and Guenther, }\end{array}$ \\
\hline SIZE & The natural logarithm of total assets & \multicolumn{2}{|c|}{} \\
\hline
\end{tabular}




\begin{tabular}{|l|l|l|}
\hline & & 2017 \\
\hline AGE & The corporate listing age & Saeidi et al., 2015 \\
\hline LEVE & Operating leverage multiplied by financial leverage & Fosu et al., 2016 \\
\hline DEBT & The total debt divided by total assets & Lozano et al., 2016 \\
\hline CR & The current assets divided by current liabilities & Kuzey and Uyar, 2017 \\
\hline Year effect & $\begin{array}{l}\text { Time dummies to control for common macroeconomic } \\
\text { effects }\end{array}$ & Coad A et al., 2016 \\
\hline $\begin{array}{l}\text { Industry } \\
\text { effect }\end{array}$ & $\begin{array}{l}\text { Industry dummies to control for common shocks at industrial } \\
\text { level }\end{array}$ & Lins et al., 2017 \\
\hline
\end{tabular}

